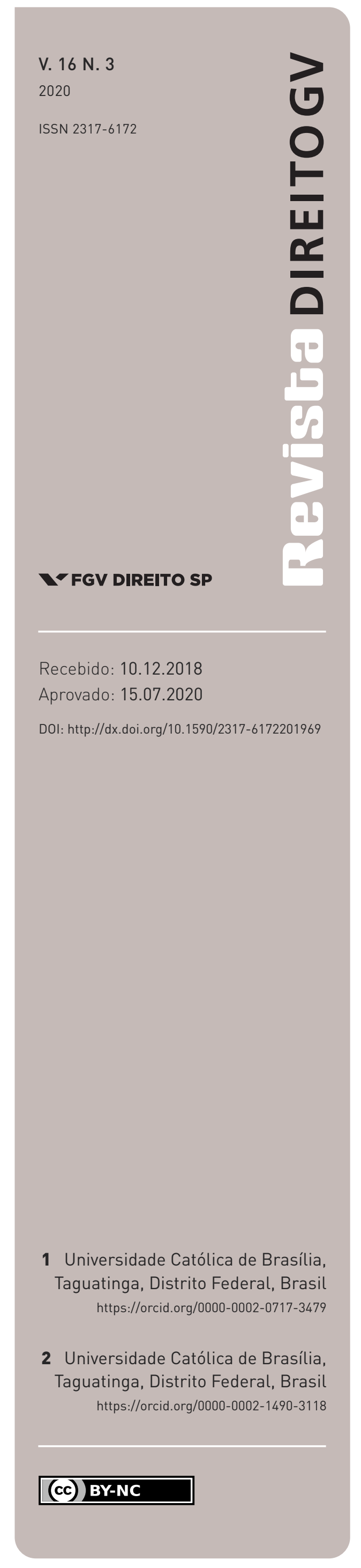

\section{"Desde que começa a ação da justiça, cessa a ação da polícia": as reformas da justiça criminal no Brasil do século XIX}

"THE POLICE WORK CEASES WHEN IT STARTS JUDICIAL PROCEEDINGS": THE CRIMINAL JUSTICE REFORMS IN NINETEENTH-CENTURY BRAZIL

Thiago Pinheiro Corrêa ${ }^{1}$ e Nefi Cordeiro ${ }^{2}$

\section{Resumo}

0 trabalho resgata o contexto histórico das reformas judiciárias no Brasil ao longo do século XIX, com enfoque no processo de gradual separação funcional e especialização das atividades judiciárias e policiais. Investiga as razões que levaram às sucessivas reformas por meio de revisão bibliográfica e consulta aos debates parlamentares da época. Defende, nesse contexto, que, para além do estabelecimento de procedimentos judiciários, as reformas veicularam concepções de justiça criminal distintas, e analisa como, e em que medida, o Código de Processo Criminal de 1832, a Lei de 3 de dezembro de 1841 e a Lei n. 2.033 de 1871 regularam as relações recíprocas entre a polícia e o Poder Judiciário, com especial destaque para a criação do inquérito policial e das consequências processuais advindas desse instrumento.

\section{Palavras-chave}

Justiça criminal; reformas; século XIX; Brasil; polícia; Poder Judiciário.

\section{Abstract}

The paper presents the historical background of Brazil's 19th-century criminal justice reforms, focusing on the process of gradual specialization of judicial and police activities. It stresses the political framework that led to successive reforms through a bibliographic review and analyses of political debates of the 19th century. It defends that, beyond criminal proceedings, the reforms incorporated different ideologies of criminal justice e analyses how and in what measure the 1832's Code of Criminal Procedure, the Law of 3 of December 1841 and the Law 2.033 of 1871 regulated the interactions between the police and the Judiciary branch, with special interest in the "inquérito policial" and what were the consequences of this legal instrument.

\section{Keywords}

Criminal justice; reforms; 19th century; Brazil; policing; Judiciary Branch. 


\section{INTRODUÇÃO}

Na exposição de motivos do Código de Processo Penal de 1941 (CPP/1941) (BRASIL, 1941), o então Ministro Francisco Campos afirmou que a nova legislação nascia da "necessidade de coordenação sistemática das regras do processo penal num Código único para todo o Brasil". Apesar de destacar as novidades da nova legislação, o Ministro reconheceu que o CPP/1941 não alteraria substancialmente o direito então vigente, tendo sido, tanto quanto possível, "aproveitado o material da legislação atual, senão para corrigir imperfeições apontadas pela experiência, dirimir incertezas da jurisprudência ou evitar ensejo a versatilidade dos exegetas".

Dentre as "práticas e critérios tradicionais" mantidos pelo CPP/1941, destaca-se o inquérito policial, encarado como "processo preliminar ou preparatório da ação penal" cujas "características atuais" foram, de acordo com a exposição de motivos, preservadas. Ao justificar a manutenção desse modelo, o Ministro da Justiça afirmou que o juizado de instrução - "que importaria limitar a função da autoridade policial a prender criminosos, averiguar a materialidade dos crimes e indicar testemunhas" - não seria compatível com a imensidão do território nacional. O adequado funcionamento do juizado de instrução dependeria da "fácil e rápida” superação das grandes distâncias geográficas entre as unidades judiciárias, a menos que o juiz instrutor detivesse, segundo o Ministro, o "dom da ubiquidade”.

A comparação com juizado de instrução havia razão de ser. Alguns anos antes, uma comissão composta por juristas havia apresentado uma proposta de codificação que rejeitava, explicitamente, o inquérito policial. Ao indicar os "defeitos do sistema legal vigente", a exposição de motivos do anteprojeto constatou o que seria um "lastimável atraso" da legislação processual penal brasileira (RÁO, FARIA e CASADO, 1938, p. 155):

Diga-se a verdade por inteiro e com coragem: - à apuração da responsabilidade criminal não se procede, hoje ainda, em juízo, mas perante a polícia. Esta, ao em vez de se limitar às funções de investigação e manutenção da ordem, forma o conteúdo do processo e, antecipando-se às autoridades judiciárias, pratica atos inequivocamente processuais, tais, por exemplo, as declarações do acusado e o depoimento das testemunhas, que toma por escrito. É ao que se chama de "inquérito" ou seja, a peça donde o Ministério Público, raramente colaborador de sua feitura, extrai os elementos para a denúncia, escolhe a dedo o rol de testemunhas de acusação e colhe a indicação das demais provas, inicialmente constituídas, todas elas, pelo espírito obliterado, que a prática do ofício determina, da autoridade policial respectiva.

O modelo de inquérito policial, de acordo com a comissão, faria com que a ação penal, uma vez ajuizada, se transformasse na "reprodução dos depoimentos, circunstâncias indiciárias, declarações, exames e vistorias já constantes dos autos do inquérito", ou seja, a "ratificação do inquérito". Essa situação geraria "duplo prejuízo": para a sociedade, que não conseguiria 
responsabilizar criminalmente "qualquer delinquente habilmente patrocinado", e para o próprio acusado, sempre em risco de se submeter a uma "surpresa judiciária” (RÁO, FARIA e CASADO, 1938, p. 156). A alternativa proposta pela comissão, nesse contexto, seria a eliminação do inquérito policial e a sua substituição pelo juizado de instrução - ainda que essa solução, conforme reconhecido na própria exposição de motivos, fosse criticada, ela própria, em outros países. ${ }^{1}$

Essa sugestão acabou não acatada pelo Governo, que, sob a égide da Constituição Federal de 1937, decretou o CPP/1941 e manteve o inquérito policial, compreendido pelo Ministro da Justiça como "instrução provisória antecedendo a propositura da ação penal” (BRASIL, 1941). O CPP/1941 materializou, nesse contexto, o que a comissão de juristas responsável pelo anteprojeto de 1935 criticava com mais intensidade na investigação criminal de então: o inquérito policial teve reafirmada a sua natureza de instrução preliminar exclusivamente policial, uma instrução que, mesmo sem integrar formalmente a ação penal, produzia uma série de consequências (processuais ou não) em juízo. ${ }^{2}$

Vê-se, portanto, que o Governo Federal de então expressamente avaliou - e rejeitou o juizado de instrução e, ao fazê-lo, justificou a manutenção do inquérito policial na legislação processual penal que, a partir de 1941, viria a se tornar comum a todo o país. A expressão "inquérito policial” detinha, no entanto, um conteúdo muito específico. Como visto anteriormente, traduziu a ideia de uma instrução prévia à ação penal, de natureza exclusivamente policial. Nessa etapa pré-processual seria reduzida a intervenção judicial e ainda menor a participação do próprio investigado. O que o Governo pretendeu, portanto, foi manter

1 Sem pretender eventual "transição brutal” entre o modelo então vigente e o juizado de instrução, a comissão acabaria propondo iniciativas investigativas concorrentes entre o juiz instrutor e a autoridade policial. Essa atuação concorrente é exemplificada no projeto (RÁO, FARIA e CASADO, 1938, p. 157).

2 Os artigos que disciplinam o inquérito policial jamais foram objeto de reformas processuais penais posteriores, de modo que, nos termos do CPP/1941, a iniciativa policial dessa instrução prévia se mantém, ainda hoje. Tal iniciativa policial é materializada pela quase exclusiva gestão, pela Polícia, da notícia-crime. O art. $5^{\circ}$, I, prevê, por exemplo, uma iniciativa autônoma da Polícia para a instauração do inquérito policial, ainda que compartilhada com o Ministério Público e Poder Judiciário. Além disso, pelo prazo 10 (em caso de prisão em flagrante) ou 30 dias (no caso de investigado solto), a Polícia detém plena autonomia para realizar as diligências que entender necessárias à elucidação do caso (art. 10, caput). A intervenção do Sistema de Justiça (Ministério Público ou Poder Judiciário) somente ocorre se houver necessidade de novos prazos para o término da apuração (art. 10, parágrafo $3^{\circ}$ ) ou caso o Ministério Público requisite novas diligências (art. 16). Deve-se ter em mente, contudo, que os dispositivos ora mencionados se encontram com suas redações originais de 1941, época em que o Ministério Público não detinha a titularidade privativa da ação penal pública (art. 129, I, da CRFB/1988), tampouco a atribuição para o controle externo da atividade policial (art. 129, VII, da CRFB/1988). Para uma interpretação do inquérito policial e de seus procedimentos, à luz da CRFB/1988, ver: ÁVILA (2016). 
os contornos gerais de uma específica estrutura de justiça criminal: uma justiça criminal em que a iniciativa (da investigação e, consequentemente, da ação penal) fosse mantida nas mãos do Poder Executivo, e não entregue à responsabilidade de juízes instrutores vinculados ao Poder Judiciário.

É nesse contexto que se deve interpretar a afirmação, inserida no anteprojeto de 1935 , de que a "apuração da responsabilidade criminal" ocorria, de fato, perante a Polícia, e não em juízo, na medida em que a etapa processual apenas reproduziria o que se havia realizado na etapa “pré-processual”. Essa, portanto, a principal crítica do anteprojeto de 1935. Uma crítica que, se não questionou a necessidade de uma investigação criminal anterior à ação penal, ${ }^{3}$ mirou o conteúdo e, especialmente, as consequências desta particular forma de investigação: uma investigação amplamente dominada pelo elemento policial e com frágeis interações com o sistema de justiça. ${ }^{4}$

A expressão "inquérito policial" - e o modelo de justiça criminal que ele representava -, todavia, não foram criados por Francisco Campos. A própria exposição de motivos do CPP/1941 reconheceu que a inspiração havia sido buscada no passado. A expressão "inquérito policial”, a seu turno, foi incorporada ao vocabulário jurídico brasileiro em 1871, ano em que foram editados a Lei n. 2.033/1871 e o seu decreto regulamentador, n. 4.824/1871 (BRASIL, 1871a; BRASIL, 1871b). Somados, lei e decreto consumaram a segunda grande reforma judiciária por que passou o Código de Processo Criminal de 1832 (CPP/1832), primeira codificação processual penal do Brasil recém-independente e um dos mais relevantes

3 Quanto à repetição dos atos praticados no curso do inquérito policial, a exposição de motivos do anteprojeto consignou: "Pondere-se bem no seguinte: - as declarações e depoimentos produzidos perante a polícia, em princípio, não têm o valor legal de prova. Pois bem, quando o acusado e as testemunhas são ouvidas de novo em juízo, longo tempo já decorreu da prática do crime, longo tempo que sempre produz uma alteração da verdade, ora obtida pelos interessados, ora provocada, em boa-fe, pelo próprio tempo ou pela interpretação que no ânimo da testemunha se forma, sob a influência do noticiário, dos comentários, da imaginação, enfim, do feitio psíquico de cada qual - o que tudo torna a repetição das provas, inclusive o novo exame dos vestígios do crime desaconselhável, sob qualquer aspecto que seja” (RÁO, FARIA e CASADO, 1938, p. 156).

4 As críticas do anteprojeto de 1935 diziam respeito ao conteúdo da investigação instrumentalizada pelo inquérito, e não à existência, pura e simples, de uma investigação preliminar à ação penal. Referiam-se à preponderância do elemento policial em detrimento da participação das instituições de Justiça (Ministério Público e Poder Judiciário). Na exposição de motivos do CPP/1941, por outro lado, o Ministro Francisco Campos argumenta que a manutenção do inquérito policial seria necessária como mecanismo de investigação criminal, ao afirmar que, "enquanto inquérito preparatório, assegura uma justiça menos aleatória, mais prudente e serena” (BRASIL, 1941). Com esse argumento, o Ministro não chegou a responder às críticas que haviam sido lançadas pelo anteprojeto de 1935, direcionadas, que eram, não à investigação preliminar em si, mas ao conteúdo e à ideologia desse mecanismo de investigação. 
produtos legislativos do período classificado por Flory (2015, p. 5) como a "fase verdadeiramente revolucionária da independência brasileira” (1827-1837). Nesse período, leis fortemente influenciadas pela ideologia liberal pós-independência (LOPES, 2017, p. 104) buscavam servir de instrumento à descentralização política do Império, o que, sob a perspectiva judiciária, foi alcançado com a instituição de uma magistratura leiga e eleita localmente. Essa novidade - e tudo o que ela representava - viria a ser combatida com a lei de 3 de dezembro de 1841, que, ao reformar o CPP/1832, buscou centralizar a persecução penal nas mãos do Executivo imperial. Para tanto, concentrou funções policiais e judiciais em agentes vinculados, organicamente, ao Poder Executivo. O inquérito policial, em 1871, representou a tentativa de separação funcional entre essas atividades.

Com o presente trabalho, pretendemos investigar as reformas judiciárias promovidas no Brasil do século XIX e, mais especificamente, analisar como e em que contexto a figura do inquérito policial - como instrumento de separação funcional entre polícia e justiça - foi introduzida em nossa legislação. Esta abordagem se justifica na medida em que o regime jurídico básico do inquérito policial permanece o mesmo, ainda hoje, desde a edição do CPP/1941 (arts. 4ª 23). Como se observa na exposição de motivos do CPP/1941, esse regime teve suas características "mantidas” e se sobrepôs à alternativa então cogitada à época, que era o juizado de instrução. Entendemos ser importante, nesse contexto, a compreensão dos motivos que, ainda no século XIX, levaram à criação desse modelo e quais desafios esse instrumento buscou confrontar. Por meio da análise de discursos políticos do século XIX, pretendemos resgatar essa importante "experiência jurídica do passado" (COSTA, 2010, p. 33) e, com isso, fornecer, na linha de Hespanha (2018, p. 29-30), "utensilagem social e intelectual" que nos sirva a reforçar o "olhar distanciado e crítico" sobre o regime jurídico do inquérito policial de hoje. Como visto anteriormente, há indícios relevantes de que o modelo gestado pelo CPP/1941 tenha sido deliberadamente inspirado nas características essenciais do inquérito policial do século $\mathrm{XIX}^{\mathbf{5}}$ de modo que, com o estranhamento oportunizado pela abordagem histórica, possamos "ver coisas diferentes na aparente monotonia do nosso tempo" (SONTAG, 2011, p. 231).

O primeiro segmento do artigo terá, como enfoque, o CPP/1832 e a reforma judiciária de 1841. Aqui, pretendemos apontar o contexto histórico que resultou na superação do sistema de 1832 e os motivos que levaram à criação de um modelo de persecução penal que sobrepunha as atividades policiais e judiciais. Buscaremos demonstrar que, longe de ter sido

5 “Apesar de algumas mudanças posteriores à Proclamação da República em 1889, continuam em vigor até hoje características importantes da estrutura institucional criada em 1841, bem como atitudes e procedimentos informais da polícia que amadureceram em meados do século XIX" (HOLLOWAY, 1997, p. 157). 
uma consequência casual da reforma, a intervenção do Executivo nas atividades judiciárias era, justamente, um dos objetivos centrais da lei de 3 de dezembro.

No segundo segmento, abordaremos a reforma judiciária de1871 naquilo que ela mais interessa ao presente artigo: o estabelecimento do inquérito policial como uma alternativa à sobreposição funcional entre polícia e justiça. Ainda nesse segmento, discorreremos sobre a principal crítica desde então direcionada ao novo modelo, relacionada à ausência de mecanismos efetivos de controle da atividade policial. De modo a permitir uma melhor compreensão da experiência jurídica objeto da análise, buscaremos tratar das reformas, em ambos os segmentos, a partir de suas relações com as condições estruturais do Brasil no século XIX.

\section{O CPP / I832 E SUA REFORMA. A LEI DE 3 DE DEZEMBRO DE I 84I}

A partir do 7 de Setembro, o novo governo enfrentou graves desafios militares e políticos. Externamente, iniciou-se a busca pelo reconhecimento da soberania brasileira e, internamente, a busca pela legitimação do poder de D. Pedro e pelo encerramento dos conflitos que ocorriam em províncias do norte. "Resta tudo a ser feito", como destacou o enviado austríaco ao Brasil, em dezembro de 1822: "Não há constituição, códigos [legais], sistema educacional; nada existe, somente um soberano reconhecido e coroado" (BARMAN, 1994, p. 102, tradução livre).

Como forma de governo, a solução monárquica nunca foi seriamente questionada, o que, segundo Carvalho (2017), deveu-se à homogeneidade da elite brasileira. As controvérsias que se seguiram à coroação disseram respeito, por outro lado, à própria justificação do poder e aos papéis a serem exercidos pelo monarca e pelo parlamento. A primeira tentativa de se estabelecer uma monarquia constitucional falhou: em 12 de novembro de 1823, D. Pedro determinou a dissolução da Assembleia Constituinte e prometeu uma constituição "duas vezes mais liberal” do que o projeto que se debatia. Outorgada a Constituição Imperial de 1824, e instalada a primeira legislatura, em 6 de maio de 1826, tinha início o projeto monárquico constitucional brasileiro.

A Constituição de 1824 pretendeu enfrentar questões políticas sensíveis. O seu art. $3^{\circ}$ estabelecia a natureza do poder imperial: monárquico hereditário, constitucional e representativo, ao tempo em que o seu art $4^{\circ}$ classificava o imperador como "defensor perpétuo" da nação. O art. $9^{\circ}$ previa a divisão "harmônica" entre os poderes Executivo, Legislativo, Moderador e Judicial, poderes esses "delegados da Nação" (art. 12) e exercidos por seus representantes, o Imperador e a Assembleia Geral (art. 11). Apesar da formal divisão dos poderes políticos, a Constituição de 1824 conferia clara preponderância à figura do Imperador, chefe do Executivo (art. 102), titular privativo do Moderador - "chave de toda a organização Política” - (art. 98) e responsável por “sancionar” a delegação conferida à Assembleia Geral (art. 13) (BRASIL, 1824).

A Constituição de 1824 estabeleceu, ainda, um Estado centralizado, dividido espacialmente em províncias "como bem pedir o Estado" (art. $2^{\circ}$ ). Seus presidentes seriam nomeados 
pelo Imperador e removíveis ad nutum (art. 165) e, em cada uma delas, seria instalado um Conselho Geral, órgão de natureza eletiva. A implementação concreta das resoluções expedidas por esses conselhos, todavia, dependeria de manifestação da Assembleia Geral (art. 85), composta pela Câmara de Deputados e Senado, este composto por membros designados pelo Imperador e titulares de mandatos hereditários (BRASIL, 1824).

Ainda que a Constituição Imperial de 1824 estabelecesse o poder a partir de bases liberais, a desconfiança causada pela brusca e violenta dissolução da Assembleia Constituinte impactaria nos trabalhos da primeira legislatura parlamentar (1826-1829). A Câmara dos Deputados, nesse contexto, foi acometida por, segundo Carvalho (apud CAMPOS, SLEMIAN e DA MOTTA, 2017, p. 14), uma "verdadeira furia legislandi", 6 com o objetivo de criar as instituições prometidas pela Constituição de 1824 que pudessem, segundo Barman (1994), reduzir o potencial hegemônico do Imperador e a "opressão e venalidade" do Poder Judicial, ainda muito associado ao regime colonial português.

Ambas as questões seriam enfrentadas, já em 1827, mediante a promulgação de duas importantes leis. A primeira definiu os crimes de abuso de poder a que estariam sujeitos os ministros e conselheiros de Estado, ${ }^{7}$ enquanto a segunda regulamentou o art. 162 da Constituição de 1824 e criou o juizado de paz, uma magistratura eletiva à qual foram atribuídas funções cíveis e criminais. Com ela, os liberais esperavam reduzir a ingerência imperial na administração da justiça. Para Flory (2015, p. 49), essa lei representou a primeira grande reforma da "década liberal" (1827-1837), e o juiz de paz, ele próprio, o símbolo do liberalismo brasileiro.

Medidas como essas aumentaram a indisposição do Imperador com as correntes liberais. A intervenção de D. Pedro I no processo sucessório português acentuou a desconfiança da população em relação a ele e à sua entourage portuguesa. Conflitos armados tomaram as ruas do Rio de Janeiro, e, em 6 de abril de 1831, uma multidão ocupou o Campo de Santana exigindo a modificação no gabinete de ministros. Já na madrugada do dia 7 de abril, D. Pedro I abdicou do trono em favor de seu filho. Nesse momento, segundo Carvalho (2018, p. 84), “o Brasil não chorava. Tomava, entusiasmado, posse de si mesmo".

Instalada a Regência, o aprofundamento das reformas liberais foi alcançado por meio da edição de outras importantes leis, ${ }^{8}$ entre elas o CPP/1832, responsável pela abolição dos

6 Ainda segundo Carvalho (apud CAMPOS, SLEMIAN e DA MOTTA, 2017, p. 14), também foram debatidos projetos de lei relacionados à criação do Supremo Tribunal de Justiça (aprovada em 1828), do Código Criminal (aprovado em 1830), dos juizados de paz (aprovado em 1827), do Código de Processo Civil (não aprovado durante todo o Império) e do Código de Processo Criminal (aprovado em 1832).

7 Para uma análise a respeito do assunto, ver: Faria (2018), especialmente o capítulo 3.

$8 \quad$ Além do CPP/1832, também foram editadas, entre 1831 e 1834, a lei de criação da Guarda Nacional (1831) e do Ato Adicional (1834). Para uma análise da Guarda Nacional, ver Holloway (1997, p. 87-90). 
juízos medievais extraordinários, regulamentação do procedimento judicial na primeira instância e reorganização da estrutura judiciária brasileira (LOPES, 2017, p. 38). Em termos de investigação criminal, eram eliminadas as devassas, atribuindo-se ao Poder Judicial a atividade de formação de culpa em procedimento contraditório, a cargo dos juízes de paz (LOPES, 2014, p. 277), a quem incumbia, ainda, o julgamento de crimes menos graves.

Formada a culpa, iniciava-se, em regra, o júri, em procedimento bipartido, composto pelo de acusação e pelo de sentença. ${ }^{9} \mathrm{O}$ primeiro conselho de jurados seria responsável pela análise de eventual justa causa para se iniciar o processo penal (art. 244 do CPP/1832), enquanto o segundo, pela análise dos fatos que compunham o mérito (art. 269 do CPP/1832). Ao juiz de Direito caberia “aplicar a lei aos fatos” (art. 46 do CPP/1832).

A despeito das profundas reformas administrativas e procedimentais concretizadas pelo CPP/1832, o seu caráter verdadeiramente revolucionário estava na outorga de novas e mais numerosas atribuições aos juízes de paz, especialmente as de natureza criminal. A partir de então, magistrados leigos e eleitos localmente passariam a prender suspeitos (art. 12, parágrafo $5^{\circ}$ ), julgar determinados tipos de crimes e contravenções (art. 12, parágrafo $7^{\circ}$ ) e arbitrar fianças (art. 12, parágrafo $6^{\circ}$ ). Além de atribuições de natureza judicial, os juízes de paz também seriam responsáveis por medidas de polícia, como tomar conhecimento de pessoas “desconhecidas" ou "suspeitas” (art. 11, parágrafo $1^{\circ}$ ), obrigar à assinatura de termos de bem viver e de confiança (art. 12, parágrafo $2^{\circ}$ ) e dividir os seus distritos em quarteirões (art. 12, parágrafo $8^{\circ}$ ). Aos juízes de paz também foram atribuídas as funções de proceder ao auto de corpo delito e a "formar a culpa aos delinquentes" (art. 12, parágrafo $4^{\circ}$ ). A respeito de suas funções ligadas à investigação criminal, Flory (2015, p. 64, tradução livre) afirma:

Enquanto agente oficial responsável por formar a culpa em todos os procedimentos criminais, o juiz de paz foi posicionado na base de todo o sistema de justiça criminal. Mesmo nos casos que excediam a sua jurisdição, sua atuação era fundamental porque,

9 "O nosso Código de Processo consagrou os dois júris, dando ao grand jury o nome de Júri de Acusação e ao pequeno júri o nome de júri de sentença; entretanto, não seguiu completamente o sistema inglês, isto é, não admitiu que a queixa ou denúncia pudesse ser diretamente apresentada ao Júri de Acusação. Os arts. $144 \mathrm{e}$ 145 determinam, neste ponto, o sistema do nosso código: - o Juizado de Paz, a quem era apresentada a queixa ou denúncia, depois de proceder às diligências, inquirições, interrogatório, em suma, atos de formação de culpa, pronunciava ou não o indiciado, declarando procedente ou improcedente a queixa ou denúncia. No primeiro caso, o delinquente, ficando sujeito à prisão e livramento, era o seu nome lançado no rol de culpados e o processo remetido ao Juiz de Paz da cabeça do termo, ou do distrito onde se reunia o Conselho de Jurados a fim de ser sustentada ou não a pronúncia pelo Júri de Acusação; no segundo caso, podia o queixoso ou denunciante recorrer da decisão do Juiz de Paz para o Júri de acusação" (ALMEIDA, 1911, v. 1, p. 222-223). 
ao formar a culpa, era ele o responsável por organizar e apresentar as provas a partir das quais outra instância judiciária ou o júri julgariam o caso.

A busca pela descentralização, pauta política dos liberais, avançava. O CPP/1832 representava, no contexto, a projeção judiciária desse movimento na medida em que transferia, quase completamente, do poder central, para as províncias, a capacidade para lidar com a administração da justiça. O fortalecimento dos juizados de paz significava a reafirmação da filosofia judicial defendida pelos liberais (FLORY, 2015, p. 64) e um “ataque" à então elite judicial (LOPES, 2014, p. 279-280). O auge da descentralização política seria alcançado com o Ato Adicional (BRASIL, 1834), responsável por conferir ainda maior autonomia política às províncias.

A conjuntura política era, no entanto, conturbada. D. Pedro II não assumiria o trono até 1841. O convulsionamento do ambiente político e as violentas revoltas - muitas delas de caráter separatista e republicano - registradas no período levaram à retomada do poder pelos conservadores, que, liderados por Bernardo Pereira de Vasconcelos, iniciaram o movimento regressista (FAUSTO, 2015, p. 149-151). A partir de 1837, o aparato legislativo dos liberais foi atacado. O “experimento liberal” (BARMAN, 1994) estava em risco e o CPP/1832 foi um dos principais alvos.

Em termos gerais, criticava-se o CPP/1832 por haver conferido tantas e tão variadas atribuições aos juízes de paz, integrantes de uma magistratura leiga e eleitos a despeito - ou até mesmo contra - a vontade do Governo central. Politicamente, a estrutura judiciária e policial estabelecida pelo CPP/1832 era considerada excessivamente descentralizada e ineficiente. Holloway (1997, p. 156) aponta para a "anomalia" de serem "o chefe e a maioria dos agentes de polícia nomeados pelo governo central, enquanto os juízes de paz eram eleitos localmente". Juridicamente, os juízes de paz eram acusados de mal desempenharem as suas funções, ${ }^{\mathbf{1 0}}$ de modo que a defeituosa formação dos processos levaria à (considerada) elevada taxa de absolvições (VELLASCO, 2007). ${ }^{11}$

A promessa de reafirmação da unidade - abalada pelas revoltas regenciais - e eficiência judiciária passava, necessariamente, pela revisão das leis editadas entre 1831 e 1836. Restaurar

10 A respeito do pouco crédito que os juízes de paz detinham, à época: "Luis Carlos Martins Pena (1815-1848), considerado um dos fundadores da comédia dos costumes no Brasil, viveu pouco, mas deixou uma obra relativamente extensa e de qualidade. Martins Pena trata do cotidiano do Império. Em $O$ juiz de paz na roça (1833), o autor mostra o juiz de paz como um ignorante que não tinha conhecimento do direito, autoritário, usando de sua influência política para se beneficiar. Vê-se que a polêmica entre liberais e conservadores sobre as atribuições do juiz de paz não era uma equação fácil de ser resolvida como se poderia imaginar" (LOPES, QUEIROZ e ACCA, 2013, p. 298).

11 "No entender dos políticos nacionais, o juiz de paz revelara-se um fracasso quase total no controle da atividade ilícita" (HOLLOWAY, 1997, p. 157). 
a paz nas províncias e fortalecer a unidade política da nação foram os objetivos centrais do novo governo conservador, instalado em setembro de 1837. A estratégia consistia na redução dos poderes provinciais e centralização do aparato de persecução penal, objetivos que viriam a ser alcançados com a edição, respectivamente, da Lei de Interpretação ao Ato Adicional (1840) e da Lei 261 (1841), mais conhecida, esta, como "lei de 3 de dezembro", data de sua aprovação.

Registre-se, no entanto, que o regresso conservador não foi alcançado a partir de uma ruptura política fundamental. Ele foi conduzido, na verdade, pela mesma elite que, anos antes, era entusiasta das reformas liberais. Naquele momento, contudo, os riscos de uma possível fragmentação política uniram a elite - homogênea em termos ideológicos e de treinamento (CARVALHO, 2017) - em torno da unidade. ${ }^{12}$ Exemplo disso é personificado na figura de Bernardo Pereira de Vasconcelos, político mineiro que se transformou em um dos símbolos do regresso. Na condição de Ministro da Justiça, Bernardo Pereira de Vasconcelos criticou duramente o sistema judiciário e a organização da Polícia. No centro dessas críticas, estava o juizado de paz, magistratura em relação à qual ele próprio havia sido um entusiasta anos antes (CAMPOS, SLEMIAN e DA MOTTA, 2017). Para ele, o próprio CPP/1832 deveria ser alterado porque (BRASIL, 1838, p. 14):

Infelizmente não satisfaz as necessidades públicas o nosso Código de Processo, nem pelo que respeita a organização Judiciária, nem pelo que toca às habilitações, e qualificações dos Juízes, nem pela parte que é relativa à ordem, e marcha do Processo até a execução da Sentença. Os meus antecessores me dispensarão de fazer reflexões sobre este objeto, havendo em seus Relatórios esgotado, e contado a matéria com exatidão, amplitude e clareza.

A reforma do CPP/1832 viria a ser aprovada em 1841 com a edição da lei de 3 de dezembro. Ela esvaziou as atribuições dos juízes de paz e as transferiu aos chefes de polícia, que, indicados pelos presidentes provinciais, atuariam por meio de seus delegados e subdelegados (arts. $1^{\circ}, 4^{\circ}$, parágrafo $1^{\circ}$ e $6^{\circ}$ ). Os chefes de polícia seriam nomeados dentre os desembargadores ou juízes de direito e seriam demissíveis a qualquer tempo $\left(\operatorname{art} .2^{\circ}\right)$. A competência para julgamento de determinados crimes e - talvez mais importante -

12 Ainda que se tratasse de uma elite "não representativa da população do país", prossegue Carvalho (2017, p. 230-231): "O núcleo da elite brasileira, pelo menos até um pouco além da metade do século, era formado de burocratas - sobretudo de magistrados - treinados nas tradições do mercantilismo e absolutismo portugueses. A educação em Coimbra, a influência do direito romano, a ocupação burocrática, os mecanismos de treinamento, tudo contribuía para dar à elite que presidiu a consolidação do Estado imperial um consenso básico em torno de algumas opções políticas fundamentais”. 
a atribuição para a formação da culpa, base de todo o sistema de justiça criminal, passavam às mãos do governo central. A lei de 3 de dezembro serviu, portanto, como um instrumento para a centralização política (SODRÉ, 1998, p. 282). E um instrumento dos mais relevantes já que, a partir dela, o governo passou a controlar, diretamente, os rumos da persecução penal.

Em termos políticos, a nova legislação enfraqueceu as autonomias locais ao transferir a administração da justiça para a órbita do governo central. Toda a estrutura judiciária passaria a ser nomeada, direta ou indiretamente, pelo Ministério da Justiça, a ponto de Tavares Bastos (1870, p. 165) afirmar que a lei de 3 de dezembro "centralizou o Império nas mãos do ministro da justiça, generalíssimo da polícia, dando-lhe por agentes um exército de funcionários hierárquicos, desde o presidente de província e o chefe de polícia até o inspetor de quarteirão". Ao fazê-lo, a persecução penal passou às mãos do Poder Executivo, tendo sido ampliado em larga escala o espectro de atuação policial (HOLLOWAY, 1997, p. 158).

Tão ampla reestruturação parece ter conferido maior agilidade e eficiência à persecução penal. Nesse sentido, Vellasco (2007) apresenta indícios que apontam para a redução no tempo entre o início e o fim do processo criminal e a maior proximidade da polícia com o fato criminoso. Ele também registra que, a partir da nova legislação, as avaliações dos Ministros da Justiça a respeito da administração da justiça, expressas em seus relatórios anuais, passaram a ser positivas. Essa mudança de humor é facilmente perceptível na comparação dos relatórios de 1841 - apresentado antes da reforma judiciária - e 1842, ambos do então Ministro Paulino José Soares de Sousa. Se, em maio de 1841 (BRASIL, 1841, p. 18), ele acentuava o "deplorável estado que se acha entre nós a administração da justiça”, já no ano seguinte (BRASIL, 1843, p. 29), editada a lei de 3 de dezembro, ele afirmava que a nova legislação "tem produzido vantagens, não sendo uma das menores haver arrancado a autoridade das mãos de muitos que se serviram ou pretendiam servir dela para envolver algumas das Províncias do Império nos horrores da rebelião".

Apesar da aparente satisfação do governo central, a lei de 3 de dezembro passou a catalisar as críticas liberais. Ao confundir as atividades policiais e judiciárias, a nova lei foi "centralizadora e policializante” (LOPES, 2014, p. 280), sendo esse “policialismo judiciário" (MARQUES, 1998 , p. 101) o principal alvo dos seus críticos. Desde a sua promulgação, havia alertas de que a execução de atividades tipicamente judiciárias, pela polícia, seria uma forma de violação ao princípio da separação de poderes e um convite à instrumentalização política do aparato policial (KOERNER, 2010, p. 36-37). Apesar das críticas, contudo, a "grande máquina policial de 1841” (NABUCO, 1897a, p. 196) não foi alvo de sérias tentativas de reforma nem mesmo durante o gabinete liberal (1844 e 1848), indício de que a nova e centralizada estrutura de persecução agradaria aos governos de ocasião.

As críticas, no entanto, efetivamente existiam e diziam respeito, principalmente, à transferência de atribuições judiciais a agentes do Executivo. Em pronunciamento perante a Câmara dos Deputados, em 1854, o então Ministro da Justiça Nabuco de Araújo, ao defender um 
projeto de reforma da legislação judiciária, reconheceu ser necessária a alteração da natureza “excepcional” da lei. Segundo ele (BRASIL, 1876, p. 116-117):

Quereis saber uma parte em que essa lei é excepcional, em que não pode deixar de considerar-se somente aplicável à sua situação? É a confusão ou acumulação do poder de prender com o poder de julgar. Certamente, senhores, repugna que em um país bem organizado a polícia esteja confundida com a justiça. Em todos os lugares, desde que começa a justiça, cessa a ação da polícia.

A fala do então Ministro da Justiça ecoava as críticas liberais. Os defensores da lei de 3 de dezembro, por outro lado - ainda que reconhecessem a "excepcionalidade" da norma -, afirmavam que ela havia sido um produto de sua época, necessária à travessia do conturbado período regencial. Durante os debates a respeito de um projeto de reforma judiciária, apresentado em 1868, o deputado Araújo Barros, ao comentar o projeto de 1845, durante a sessão de 23 de maio de 1868, reafirmou aquele que era o principal objetivo reformista (BRASIL, 1868, p. 113):

Nesse projeto a ideia capital era tirar as autoridades policiais, agentes do executivo, a faculdade de proferirem sentenças definitivas e de pronúncia. Conhecia-se então, tanto como hoje, em que temos mais de um quarto de século de experiência dessa lei, que ela, concedendo a faculdade de julgar às autoridades amovíveis ad nutum do governo, sem garantia de independência e imparcialidade, sacrificara todos os direitos políticos e individuais. Com essa lei os partidos que fossem levados ao poder se manteriam nele, influindo na eleição, e determinando em seu favor o pronunciamento das urnas.

A despeito dos esforços de Nabuco de Araújo, o projeto por ele defendido em 1854 acabou não sendo aprovado, e, depois dele, muitos outros fracassariam (MARQUES, 1998, p. 103). O aspecto mais polêmico da lei de 3 de dezembro somente seria enfrentado trinta anos depois, com a aprovação de uma nova reforma judiciária. Um dos principais objetivos da Lei n. 2.033/1871 seria a busca pela separação funcional entre atividades policiais e judiciais. O instrumento para o alcance desse propósito, o inquérito policial, seria disciplinado pelo Decreto n. 4.824/1871.

\section{A LEI N. 2033, DE 20 DE SETEMBRO DE I87I, E O DECRETO N. 4824, DE 22 DE NOVEMBRO DE I87I}

Em 3 de maio de 1871, ao inaugurar o ano legislativo com uma de suas tradicionais "falas do trono" (BRASIL, 1889, p. 667-670), D. Pedro II destacou três importantes questões estruturais por que passava o Brasil: (i) as negociações com o Paraguai; (ii) a necessidade de reforma da legislação sobre o "estado servil"; e (iii) a necessidade de uma reforma judiciária. 
A respeito do primeiro item, D. Pedro II afirmou estarem em andamento as tratativas para os "ajustes definitivos de paz" com o Paraguai. No Brasil, contudo, os efeitos econômicos e sociais da guerra ainda se fariam sentir. O esforço de guerra brasileiro havia culminado com o aumento de impostos, emissão de moeda e endividamento internacional. O retorno dos soldados brasileiros ao país, por outro lado, foi encarado com reservas pela Coroa, que antevia a possibilidade de os então combatentes se transformarem em vetores de epidemias e de insurreições populares. Nessa conta, havia especial preocupação com os escravos que, enviados aos campos de batalha, haviam alcançado a liberdade. Rodrigues (2009) calcula o total de 7.414 escravos libertos que haviam combatido pelo Brasil durante a guerra.

Outra pauta mencionada por D. Pedro II, a reforma da legislação sobre o "estado servil", viria a ser enfrentada mediante a aprovação, em 28 de setembro de 1871, da Lei n. 2.040/ 1871 (BRASIL, 1871c), mais conhecida como a Lei do Ventre Livre. Carvalho (2017, p. 304-305) situa a aprovação dessa lei em um "segundo momento importante do processo decisório" que culminou com a abolição definitiva, em 1888. Segundo ele, esse novo "ciclo decisório" iniciou-se em 1867, a partir de provocação do próprio Imperador. Ao citar Nabuco de Araújo, Carvalho (2017, p. 305) afirma que uma das primeiras manifestações públicas da Coroa a favor da abolição teria tido "[...] o efeito de um raio caindo do céu sem nuvens. Ninguém esperava tal pronunciamento. Tocar assim na escravidão pareceu a muitos, na perturbação do momento, uma espécie de sacrilégio histórico, de loucura dinástica, de suicídio nacional".

Os debates foram intensos no âmbito do Conselho de Estado (NABUCO, 1897b), no qual propostas de abolição, puras e simples, eram confrontadas por outras, que previam a abolição gradual. Segundo Carvalho (2017, p. 307-308):

Mas a abolição imediata parecia a todos impraticável pois perturbaria toda a produção e, a ser feita com indenização, arruinaria as finanças do país. Daí que o mal menor era a abolição gradual acompanhada de medidas acauteladoras para enfrentar o provável aumento das inquietações escravas e mesmo possíveis rebeliões. Antes, disse, Nabuco, as perturbações que houve em Guadalupe e Martinica do que a explosão de Santo Domingo. Quer dizer, havia uma aguda consciência do perigo que representava para a ordem pública a agitação da massa escrava, embora essa agitação ainda fosse, no momento, mais potencial do que real.

Aprovada, a Lei n. 2.040/1871 declarou livres os filhos de mulheres escravas que nascessem a partir de sua edição (art. $1^{\circ}$, caput). Previu, ainda, que os menores livres ficariam "sob a autoridade dos senhores de suas mães" até os 8 anos de idade (art. $1^{\circ}, \S 1^{\circ}$ ) (BRASIL, 1871c). A partir de então, a Coroa deteria - ao menos em tese - instrumentos legais para fiscalizar o que acontecia no interior das fazendas. Chalhoub (2018, p. 74) menciona, no entanto, que regras dessa natureza aguçaram o "ressentimento dos grandes proprietários quanto à 
intervenção do poder público nas relações entre senhores e escravos", na medida em que a "lei criava direitos aos quais os escravizados poderiam recorrer e conferia ao poder público a prerrogativa de fiscalizar o que se fazia dentro das fazendas". ${ }^{13}$

Também em sua fala do trono, D. Pedro II instava os parlamentares a aprovarem uma nova reforma judiciária que pudesse "extremar a ação da polícia, reduzida às atribuições de seu peculiar serviço" (BRASIL, 1889, p. 667-668). Apenas oito dias antes de votada a Lei do Ventre Livre, em 20 de setembro de 1871, foi aprovada a Lei n. 2.033/1871 (BRASIL, 1871a), que viria a alterar profundamente a lei de 3 de dezembro. O projeto que viria a se transformar na lei fora aprovado pelo Senado e decorrera de um substitutivo à proposta da Câmara dos Deputados. Tal substitutivo fora apresentado pelo próprio Governo, na figura do então Ministro da Justiça, Sayão Lobato.

A proposta do Governo desagradou os liberais, que o acusaram de haver deturpado a natureza da proposta em debate na Câmara. De acordo com Nabuco (1897b, p. 260-261):

A Câmara mandava submeter ao júri todos os crimes por abuso de liberdade de imprensa, e Sayão Lobato suprimia essa disposição; a Câmara mandava que a prisão preventiva não pudesse ter lugar senão por mandado escrito do juiz competente, e Sayão Lobato inutilizava essa disposição. Também quanto às apelações da absolvição no júri, a Câmara era muito mais liberal do que o ministro. Em matéria de habeas-corpus, Sayão Lobato melhorava o projeto da Câmara, admitindo-o "sem exclusão dos detidos a título de recrutamento, ainda alistados como praças no exército ou armada”. Há, porém, uma emenda d' ele que Nabuco critica fortemente, é a que excluía o habeas-corpus na prisão determinada por despacho de pronúncia.

Apesar dessas críticas, no entanto, a Lei n. 2.033/1871 reformou o que a lei de 3 de dezembro tinha de mais controverso: a confusão entre as atividades de polícia e justiça. Nos termos do art. $9^{\circ}$ da nova legislação, extinguiu-se a "jurisdição dos Chefes de Polícia, Delegados e Subdelegados” em relação aos crimes previstos no art. 12, $\S 7^{\circ}$, do Código do Processo Criminal e em relação aos crimes menos graves (BRASIL, 1871a). Quanto aos crimes comuns, ainda que lhe tenha sido vedado proceder à formação da culpa, a nova lei atribuiu à polícia a tarefa de "em seus distritos proceder às diligências necessárias para descobrimento dos factos criminosos e suas circunstâncias", devendo, em seguida, transmitir ao promotor

13 O ressentimento a respeito da Lei do Ventre Livre também aparece em documentos oficiais jurídicos. Ao resgatar os autos de um processo criminal em que escravos Gil e Manoel eram acusados de homicídio, Batista (2007, p. 32) destaca as palavras do promotor responsável pela denúncia, no sentido de que o crime seria "mais uma triste consequência da fatal lei de 28 de setembro de 1871". 
público, "com os autos de corpo de delito e indicação das testemunhas mais idôneas, todos os esclarecimentos coligidos", conforme art. 10, $1^{\circ}$, da Lei n. 2.033/1871. Para alguns crimes, no entanto, a polícia permaneceu com atribuição para lhes preparar os respectivos processos “até a sentença exclusivamente”, conforme art. 10 da Lei n. 2.033/1871. ${ }^{14}$

Dentre as novas atribuições policiais, contudo, Koerner (2010, p. 100) destaca como a mais importante a criação do "inquérito policial", instituto regulamentado pelos arts. 38 a 44 do Decreto n. 4.824/1871 (BRASIL, 1871b). Tratava-se de procedimento a cargo do chefe de polícia e de seus delegados e subdelegados e que compreendia as "diligências necessárias para verificação da existência do mesmo crime, descobrimento de todas as suas circunstâncias e dos delinquentes" (art. 38). O inquérito policial, nesse contexto, serviu como instrumento para a cisão funcional entre as atividades policial e judicial, mediante o estabelecimento de atribuições a serem exercidas por autoridades distintas - policiais e judiciárias -, em momentos temporais e com objetivos igualmente distintos. Essa cisão funcional, da forma como estabelecida, contudo, acabou por garantir ampla margem de discricionariedade à polícia, uma vez que o novo modelo "[...] mantinha a iniciativa de ação da polícia na instrução criminal, independentemente da intervenção da autoridade judiciária” (KOERNER, 2010, p. 100).

A reforma efetivamente extinguiu as competências judicantes da polícia, o que não significa dizer que tenha restringido ou eliminado a influência do elemento policial na atividade desenvolvida em juízo. O novo modelo, na tentativa de delimitar, funcionalmente, as atividades judiciais e policiais, criou, na prática, uma espécie de procedimento preparatório à ação penal, de responsabilidade exclusiva da polícia e, na prática, infenso a controles judiciais. Assim, ainda que o inquérito policial representasse, em tese, um mecanismo de controle sobretudo ao prever prazos para o encerramento das investigações ${ }^{15}$, acabou por separar, abruptamente, a atividade policial da atividade judiciária propriamente dita. Com isso, a solução do inquérito policial, ao prolongar a formação da culpa, retardou a introdução do caso criminal no sistema de justiça, ao mesmo tempo que outorgou ampla liberdade de atuação

“A reforma de 1871 retirou da polícia o poder de julgar as infrações dos termos de segurança e bem viver, atribuições que foram transferidas para os juízes de paz. Quanto aos crimes policiais, foi transferido para o julgamento para os juízes municipais [sic], mas permaneceu com as autoridades policiais a atribuição de preparar os processos, o que significa que foi mantida a sua autonomia de ação neste nível” (KOERNER, 2010, p. 100).

15 "Abusando dessa atribuição [investigativa], as autoridades policiais muitas vezes excediam-se, procedendo a quase devassas.

$[\ldots]$

Para cortar o abuso, que se fundava no pretexto da dificuldade da indagação das provas, a Lei n. 2033 de 20 de Setembro de 1871 criou o inquérito policial, cujas diligências devem ser terminadas, se o réu estiver preso, no prazo de cinco dias" (ALMEIDA, 1911, v. 2, p. 65). 
aos agentes policiais, ainda vinculados ao Poder Executivo (KOERNER, 2010, p. 101). Antes mesmo da aprovação da nova lei, durante a sessão parlamentar de 31 de julho de 1871, o senador Thomaz Pompeu de Souza Brasil criticou esta, que viria a ser uma das consequências relevantes da reforma judiciária (BRASIL, 1871d, p. 217):

Os delegados e subdelegados não julgam mais, é verdade, porém preparam os processos dos crimes do art. $12 \S 7^{\circ}$ do código do processo; e, se como disse muito bem o honrado Sr. ministro da justiça, o julgamento não é mais do que a consequência dessas premissas, segue-se que o juiz tem necessariamente de julgar pelos olhos dos delegados e subdelegados que lhe preparam as premissas para tirar a consequência.

Assim, ainda que as hipóteses de jurisdição policial tenham sido extintas, a importância do elemento policial para o processo penal foi mantida, já que a atividade judiciária, como regra, decorreria de uma instrução administrativa prévia, a cargo dos delegados e subdelegados, a quem competia a realização, por meio do inquérito policial, de todas as "diligências para o descobrimento dos fatos criminosos e suas circunstâncias" (art. 11, item $2^{\circ}$, do Decreto n. 4.824/1871) (BRASIL, 1871b). Quanto à condução desse elemento policial, no entanto, a lei não previa mecanismos que garantissem a sua vinculação ao controle pelo Poder Judiciário. Nabuco (1897b, p. 263) registra a insatisfação de Nabuco de Araújo com a inserção de "emendas restritivas" por parte do Governo e o comentário do ex-Ministro da Justiça: "O que falta neste projecto e o torna defectivo aos olhos do partido Liberal? O que falta está exposto no voto em separado e se resume n'estes dois pontos: uma magistratura como deve ser, uma organização judiciaria capaz de garantir as liberdades individuaes". ${ }^{16}$

Vê-se, portanto, que, em um ambiente de incertezas a respeito das repercussões de medidas abolicionistas, o Governo manteve para si, na prática, a iniciativa para a persecução penal, ainda que, à primeira vista, pareça ter desmontado o regime jurídico centralizador instituído pela lei de 3 de dezembro. ${ }^{17}$

16 Na nota de rodapé associada a este trecho, Nabuco (1897b, p. 263) registra: "Em 1876 Nabuco redigirá o parecer do Instituto dos Advogados, consultado por Diogo Velho (Visconde de Cavalcanti) sobre diversas alterações que pretendia propor em relação à justiça. N'esse trabalho elle pronuncia-se pelo noviciado regular para a magistratura e para a advocacia; pela suppressão da appellação do Juiz de Direito no Jury; por tribunaes correccionaes; pela suppressão dos inquéritos policiaes; etc. Esse parecer é acompanhado do voto em separado de Octaviano, sobre o modo de organizar a profissão de advogado".

17 Faltam-nos elementos, neste momento, para concluir que essa decisão tenha sido efetivamente deliberada e pretendida pelo Governo. De toda forma, entendemos ser passível de reservas, a partir de tudo o que exposto neste trabalho, a afirmação de Carvalho (2017, p. 315) no sentido de que: "Pode-se assim dizer que, apesar 


\section{Conclusão}

Ao longo do século XIX o Brasil experimentou reformas judiciárias que detinham ideologias e objetivos diametralmente opostos. Se, de um lado, o CPP/1832 descentralizou as atividades judiciais e ampliou, sem precedentes, a participação popular na administração da Justiça, a lei de 3 de dezembro ocupou espectro ideológico oposto, ao centralizar a persecução penal em uma estrutura hierárquica, coesa e ligada, diretamente, à Coroa. Entre essas duas reformas, a Lei n. 2.033/1871 pretendeu separar as funções judiciais e policiais mediante a criação de um espaço de atuação próprio da polícia.

Mais do que materializarem simples regras procedimentais, as reformas judiciárias do século XIX veicularam concepções distintas sobre o perfil da justiça criminal brasileira. O inquérito policial encaixa-se neste contexto: ainda que tenha servido à efetiva separação funcional entre Polícia e Justiça, ele funcionou - deliberadamente, ou não - como mecanismo de manutenção, junto ao Poder Executivo, da iniciativa para a instrução criminal. Se, por um lado, a Lei n. 2.033/1871 contribuiu para a profissionalização da magistratura (HOLLOWAY, 1997, p. 228) mediante a cessação da jurisdição policial, delimitou, por outro lado, um espaço de "não atuação" judicial: de natureza exclusivamente policial, o inquérito passou a ser conduzido por autoridades administrativas vinculadas, organicamente, ao Poder Executivo e que detinham ampla liberdade de iniciativa. O art. 44 do Decreto n. 4.824/1871 (BRASIL, $1871 b$ ) dá a medida dessa liberdade ao prever que os juízes competentes somente tomariam conhecimento do inquérito após a remessa dos autos pelas autoridades policiais. A participação da autoridade judiciária competente não seria, portanto, a regra, mas elemento acidental da instrução policial (art. 43 do Decreto n. 4.824/1871).

Estas, portanto, talvez sejam as características fundamentais do modelo de justiça criminal estabelecido a partir de 1871: a instrução policial-administrativa plena e anterior à submissão do caso ao sistema de justiça. Estas foram, justamente, as características que o anteprojeto de 1935 pretendeu suprimir - mediante a criação do juizado de instrução - e as

características que os autores do CPP/1941, deliberadamente, mantiveram. ${ }^{18}$ A previsão de instrumentos jurídicos para o controle da atividade policial (especialmente da investigação criminal) somente apareceria na Constituição Federal de 1988 (CRFB/1988), mediante o estabelecimento de um regime jurídico que lhe permite, ao mesmo tempo, controlar a atividade policial e garantir a inércia da atividade judicial (art. 129, I, VII e VIII, da CRFB/1988).

das previsões pessimistas dos próprios partidários do Ventre Livre quanto a rebeliões de escravos, o governo não procurou reforçar sua capacidade repressiva ao passar a lei [2.033/1871], antes a enfraqueceu".

18 A natureza de instrução preliminar à ação penal é reforçada na própria exposição de motivos, conforme visto na introdução. Essa instrução policial é plena na medida em que o CPP/1941 confere ampla liberdade de atuação à polícia para realizar as diligências investigativas necessárias (art. $6^{\circ}$ ) para, só então, submeter o caso ao sistema de justiça (art. $\left.10, \S 1^{\circ}\right)$. 


\section{REFERÊNCIAS}

ALMEIDA, João Mendes de. O processo criminal brazileiro. 2. ed. aum. Rio de Janeiro: Francisco Alves e Cia, 1911. v. 1 e 2.

ÁVILA, Thiago André Pierobom de. Investigação criminal: o controle externo de direção mediata pelo Ministério Público. Curitiba: Juruá, 2016.

BARMAN, Roderick J. Brazil: the forging of a nation, 1798-1852. Stanford: Stanford University Press, 1994.

BASTOS, Tavares. Estudo sobre a descentralização no Brasil. Rio de Janeiro: B.L. Garnier, 1870.

BATISTA, Nilo. Pena pública e escravismo. In: NEDER, Gislene. História e direito: jogos de encontro e transdisciplinariedade. Rio de Janeiro: Revan, 2007.

BRASIL. Constituição Política do Império do Brasil, elaborada por um conselho de estado e outorgada pelo imperador d. Pedro I, em 25.03.1824. 1824. Disponível em: http: / /www.planalto.gov.br/ccivil_03/ Constituicao/Constituicao24.htm. Acesso em: 13 set. 2019.

BRASIL. Lei n. 16 de 12 de agosto de 1834. Faz algumas alterações e addições á Constituição Politica do Imperio, nos termos da Lei de 12 de Outubro de 1832. 1834. Disponível em: http:/ /www.planalto. gov.br/ccivil_03/leis/LIM/LIM16.htm\#art10\%C2\%A74. Acesso em: 13 set. 2019.

BRASIL. Relatório da repartição dos negócios da Justiça apresentado à Assembleia Geral Legislativa de 1838 pelo respectivo Ministro e Secretário Bernardo Pereira de Vasconcellos. Rio de Janeiro: Typographia Nacional, 1838. Disponível em: http: / /ddsnext.crl.edu $/$ titles $/ 107 \#$ ? $=0 \& \mathrm{~m}=8 \& \mathrm{~s}=0 \& \mathrm{cv}=0 \& \mathrm{r}=0 \& \mathrm{xywh}=$ 165\%2C-213\%2C4231\%2C2984. 1838. Acesso em: 13 set. 2019.

BRASIL. Relatório da repartição dos negócios da Justiça apresentado à Assembleia Geral Legislativa na Sessão Ordinária de 1841 pelo respectivo Ministro e Secretário de Estado Paulino José Soares de Sousa. Rio de Janeiro: Typographia Nacional, 1841. Disponível em: http: //ddsnext.crl.edu/titles $/ 107 \#$ ?c=0\&m=8\&s= $0 \& \mathrm{cv}=0 \& \mathrm{r}=0 \& \mathrm{xywh}=-165 \% 2 \mathrm{C}-213 \% 2 \mathrm{C} 4231 \% 2 \mathrm{C} 2984$. Acesso em: 13 set. 2019.

BRASIL. Relatório da repartição dos negócios da Justiça apresentado à Assembleia Geral Legislativa na $1^{a}$ Sessão da $5^{a}$ Legislatura pelo respectivo Ministro e Secretário de Estado Paulino José Soares de Sousa. Rio de Janeiro: Typographia Nacional, 1843. Disponível em: http://ddsnext.crl.edu/titles $/ 107 \#$ ?c $=0 \& \mathrm{~m}=12 \& \mathrm{~s}=$ $0 \& \mathrm{cv}=2 \& \mathrm{r}=0 \& \mathrm{xywh}=-1455 \% 2 \mathrm{C}-1 \% 2 \mathrm{C} 4797 \% 2 \mathrm{C} 3384$. Acesso em: 13 set. 2019. 
BRASIL. Annaes do Parlamento brazileiro: Câmara dos senhores deputados, segundo anno da décima terceira legislatura, sessão de 1868. Tomo primeiro. Rio de Janeiro: Typographia Imperial e Constitucional de J. Villeneuve \& C., 1868. Disponível em: http://bndigital.bn.br/acervo-digital/Annaes-do-parlamento/ 132489. Acesso em: 14 set. 2019.

BRASIL. Lei n. 2.033, de 20 de setembro de 1871. Altera diferentes disposições da legislação judiciária. 1871a. Disponível em: http://www.planalto.gov.br/ccivil_03/leis/lim/LIM2033.htm. Acesso em: 25 set. 2020.

BRASIL. Decreto n. 4.824, de 22 de novembro de 1871. Regula a execução da lei n. 2033 de 24 de setembro do corrente ano, que alterou diferentes disposições da legislação judiciaria. 1871b. Disponível em: http://www.planalto.gov.br/ccivil_03/decreto/historicos/dim/DIM4824.htm. Acesso em: 9 dez. 2018.

BRASIL. Lei n. 2.040, de 28 de setembro de 1871. Declara de condição livre os filhos de mulher escrava que nascerem desde a data desta lei, libertos os Escravos da Nação e outros, e providencia sobre a criação e tratamento daquelles filhos menores e sobre a libertação annual de escravos. 1871c. Disponível em: http://www.planalto.gov.br/ccivil_03/leis/lim/lim2040.htm. Acesso em: 9 dez. 2018.

BRASIL. Senado Federal. Annaes do Senado do Imperio do Brazil. Terceira sessão em 1871 da Decima Quarta Legislatura de 1 a 31 de julho. Rio de Janeiro: Typographia do Diario do Rio de Janeiro, 1871d. v. III. Disponível em: http://www.senado.leg.br/publicacoes/anais/asp/IP_AnaisImperio_digitalizados.asp. Acesso em: 9 dez. 2018.

BRASIL. Annaes do Parlamento Brazileiro: Câmara dos senhores. Deputados, segundo anno da nona legislatura, sessão de 1854. Tomo terceiro. Rio de Janeiro: Typographia de Hyppolito Jose Pinto, 1876. Disponível em: http://bndigital.bn.br/acervo-digital/Annaes-do-parlamento/132489. Acesso em: 9 dez. 2018.

BRASIL. Fallas do throno desde o anno de 1823 até o anno de 1889, acompanhadas dos respectivos votos de graças da camara temporaria e de differentes informações e esclarecimentos sobre todas as sessões extraordinarias, adiamentos, dissoluções, sessões secretas e fusões com um quadro das epochas e motivos que deram lugar a reunião das duas camaras e competente histórico. Rio de Janeiro: Imprensa Nacional, 1889. Disponível em: http://www2.senado. leg.br/bdsf/item/id/227319. Acesso em: 9 dez. 2018.

BRASIL. Decreto-lei n. 3.689, de 3 de outubro de 1941. Código de processo penal. 1941. Disponível em: http://www.planalto.gov.br/ccivil_03/Decreto-Lei/Del3689.htm. Acesso em: 8 set. 2019.

CAMPOS, Adriana Pereira; SLEMIAN, Andréa; DA MOTTA, Kátia Saussen. Juízes de Paz: um projeto de justiça cidadã nos primórdios do Brasil Império. Curitiba: Juruá, 2017. (Biblioteca de Filosofia, Sociologia e Teoria do Direito). 
CARVALHO, José Murilo de. A construção da ordem: a elite política imperial e Teatro das sombras: a política imperial. 10. ed. Rio de Janeiro: Civilização Brasileira, 2017.

CARVAlHO, José Murilo de. A vida política. In: CARVALHO, José Murilo de (org.). A construção nacional: 1830-1889. Rio de Janeiro: Objetiva, 2018. p. 83-130. v. 2, parte 2.

CHAlHOUB, Sidney. População e sociedade. In: CARVALHO, José Murilo de (org.). A construção nacional: 1830-1889. Rio de Janeiro: Objetiva, 2018. p. 37-82. v. 2, parte 1.

COSTA, Pietro. Soberania, representação, democracia: ensaios de história do pensamento jurídico. Tradução de Alexander Rodrigues de Castro, Angela Couto Machado Fonseca, Érica Hartman, Ricardo Marcelo Fonseca, Ricardo Sontag, Sergio Said Staut Jr., Walter Guandalini Jr. Curitiba: Juruá, 2010.

FARIA, Aléxia Alvim Machado. Peita, suborno e a construção do conceito penal de corrupção: patronato e venalidade no Brasil imperial (1824-1889). 224 p. Dissertação (Mestrado em Direito) - Faculdade de Direito, Universidade Federal de Minas Gerais, Belo Horizonte, 2018. Disponível em: https:/ / repositorio. ufmg.br/bitstream/1843/BUOS-B2HFKE/1/disserta_o_alexia_alvim.pdf. Acesso em: 23 jul. 2020.

FAUSTO, Boris. História do Brasil. São Paulo: Editora da Universidade de São Paulo, 2015.

FLORY, Thomas. Judge and jury in Imperial Brazil, 1808-1871: social control and political stability in the New State. Latin American Monographs, n. 53. Austin: The University of Texas at Austin, 2015.

HESPANHA, António Manuel. Cultura jurídica europeia: síntese de um milénio. Coimbra: Almedina, 2018.

HOLLOWAY, Thomas H. Polícia no Rio de Janeiro: repressão e resistência numa cidade do século XIX. Tradução de Francisco de Castro Azevedo. Rio de Janeiro: Fundação Getulio Vargas Editora, 1997.

KOERNER, Andrei. Judiciário e cidadania na Constituição da República Brasileira (1841-1920). Curitiba: Juruá, 2010. (Biblioteca de História do Direito).

LOPES, José Reinaldo de Lima. O Direito na História: lições introdutórias. 5. ed. São Paulo: Atlas, 2014.

LOPES, José Reinaldo de Lima. História da Justiça e do processo no Brasil do século XIX. Curitiba: Juruá, 2017. (Biblioteca de Filosofia, Sociologia e Teoria do Direito).

LOPES, José Reinaldo de Lima; QUEIROZ, Rafael Mafei Rabelo; ACCA, Thiago dos Santos. Curso de História do Direito. 3. ed. Rio de Janeiro: Método, 2013. 
MARQUES, José Frederico. Elementos de direito processual penal. 1. ed. 2. tiragem. Campinas: Bookseller, 1998. v. I.

NABUCO, Joaquim. Um estadista do império: Nabuco de Araujo, sua vida, suas opiniões, sua época. Por seu filho Joaquim Nabuco. Rio de Janeiro: H. Garnier, 1897a. Tomo primeiro (1813-1857).

NABUCO, Joaquim. Um estadista do império: Nabuco de Araujo, sua vida, suas opiniões, sua época. Por seu filho Joaquim Nabuco. Rio de Janeiro: H. Garnier, 1897b. Tomo terceiro (1866-1878).

RÁO, Vicente; FARIA, Antonio Bento de; CASADO, Plinio de Castro. Projeto do Código do Processo Penal da República dos Estados Unidos do Brasil. Revista da Faculdade de Direito, Universidade de São Paulo, v. 34, n. 3, p. 137-292, 1 jan. 1938. Disponível em: http://www.revistas.usp.br/rfdusp/article/ view/65837. Acesso em: 9 set. 2019.

RODRIGUES, Marcelo Santos. Guerra do Paraguai: os caminhos da memória entre a comemoração e o esquecimento. 2009. 320 p. Tese (Doutorado em História Social) - Instituto de Filosofia, Letras e Ciências Humanas, Universidade de São Paulo, São Paulo, 2009. Disponível em: http: / /www.teses.usp.br/teses / disponiveis/8/8138/tde-07122009-102220/en.php. Acesso em: 23 jul. 2020.

SODRÉ, Nelson Werneck. Panorama do Segundo Reinado. Rio de Janeiro: Graphia, 1998.

SONTAG, Ricardo. Teoria da legislação e direito penal em Jeremy Bentham: a questão dos destinatários. In: JÚNIOR, Arno Dal Ri; SONTAG, Ricardo (org.). História do direito penal entre medievo e modernidade. Belo Horizonte: Del Rey, 2011. p. 231-252.

VELLASCO, Ivan de A. A lei da reforma de 1841 e seu impacto nos padrões de operatividade da justiça. In: NEDER, Gislene (org.). História e direito: jogos de encontro e transdisciplinariedade. Rio de Janeiro: Revan, 2007. p. 197-210.

\section{COMO CITAR ESTE ARTIGO:}

CORRÊA, Thiago Pinheiro; CORDEIRO, Nefi. “Desde que começa a ação da justiça, cessa a ação da polícia”: as reformas da justiça criminal no Brasil do século XIX. Revista Direito GV, v. 16, $\mathrm{n}$. 3, set./dez. 2020, e1969. doi: http://dx. doi.org/10.1590/2317-6172201969
Thiago Pinheiro Corrêa

Graduado em Direito pela Escola de Direito do Rio de Janeiro da Fundação Getulio Vargas (FGV diREITO RIO). Pós-Graduado em Direito pela Escola Superior do Ministério Público da União. Mestre em Direito pela Universidade Católica de Brasília. Procurador da República.

thiagocorrea25agmail.com 
Nefi Cordeiro

Doutor e Mestre em Direito pela Universidade Federal do PARANÁ (UFPR), COM CONCENTRAC̣ÃO NA ÁREA CRIMINAL.

PROFESSOR UNIVERSITÁRIO - GRADUAC̣̃̃O E PÓS-GRADUAC̣̃̃O, LATO E StRICTO SENSU. Ministro do Superior TRIBUnal de Justiça.

nefi.cordeirolamsn.com 